\title{
Go-ahead for tree salvage angers US Greens
}

Washington. Large-scale logging is set to resume in the United States after President Clinton signed a budget rescission bill which includes language to exempt so-called salvage logging from environmental laws.

The forestry industry has argued for the exemption on the grounds that burnt and otherwise damaged trees should be removed in the interests of better forest maintenance. But environmentalists regard the measure as a 'front' for the resumption of extensive logging, and are livid with President Clinton for allowing its passage.

The measure is the first of the environmental changes proposed by the Republican Congress to actually pass into law, and environmental pressure groups see its signing by Clinton on 27 July as an indication that he is not prepared to confront Congress on environmental issues.

"This is a betrayal of everything Bill Clinton said he stood for," says Carl Pope, executive director of the Sierra Club, the largest environmental pressure group in the United States. Pope claims that the administration has come to a private agreement with Congressional leaders to use the new law to per- mit twice as much logging as scientists at the US Forest Service believe to be necessary.

The law essentially says that tree-clearing on public land which can be classified as "salvage logging" will be permitted by federal agencies during a year-long "emergency period", regardless of existing federal laws and international agreements.

Most ecologists agree that selective logging can be beneficial to forest management in some circumstances (see Nature 370, 585; Logging on: Salvage logging will be legal for one year. 1994), but the nature of these circumstances is hotly disputed. Environmentalists charge that the Forest Service has used salvage logging as a pretext for logging the largest trees - the only ones still alive - after forest fires.

A spokesman for the Forest Service said it could not say how it would implement the new law until it had been advised by lawyers at its parent, the Department of Agriculture.

In an ambiguously-worded memorandum to the department heads involved, Clinton

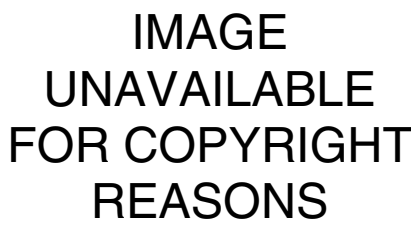

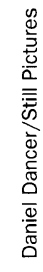
provisions in the law he had just signed. The memo nevertheless instructed the agencies "to implement these provisions in an environmentally sound manner."

The memo disappointed environmental groups, who said they planned court action to block salvage logging authorized under the new law. "We will be going to court," warned Pope. "This is an attempt to suspend the rule of law".

Colin Macilwain

\section{Medical research charities 'can rely on peer review'}

London. Britain's Charity Commissioners have backed away from an earlier proposal that the trustees of medical research charities should be held directly responsible for checking on the scientific quality of research published by their grant recipients. They have also dropped a parallel suggestion that charities be required to lay legal claim to any potential patents resulting from such research.

In draft guidelines on the conduct of research charities published in London last week, the commissioners suggest that trustees can rely on the peer review process of a "reputable scientific or medical journal" in which the results are published - although they add that, if further publicity is to be given to these results by the charity concerned, its trustees should take additional steps to satisfy themselves that the results are soundly based.

As far as intellectual property rights are concerned, the commissioners propose that all charities should be responsible for ensuring that these are adequately protected, as part of their broader responsibility for their public dissemination. But they suggest leaving open the question of whether the charity itself should file for such protection - as an earlier draft would have required - or whether this can be left to the institution at which the research is carried out.

The new guidelines have been welcomed by the Association of Medical Research
Charities (AMRC), which feared that earlier draft proposals on the monitoring and dissemination of research were too restrictive. "We are very pleased that [the proposed guidelines have] come out like this," says Diana Garnham, general secretary of the AMRC.

The responsibilities of medical charities for the impact of the research they sponsor were dramatically highlighted in 1990 by the publication of the preliminary results of a study, backed by two cancer research charities, of the activities of an alternative cancer therapy centre in Bristol.

The study, published in The Lancet, claimed that the survival rate of those treated at the alternative centre was substantially lower than that of those receiving conventional treatment. But these conclusions were subsequently withdrawn when it was revealed that they had been based on faulty statistical analysis.

Last year, following a lengthy internal discussion of the implications of the way in which the preliminary results of the Bristol study had been published, the Charity Commissioners published various draft recommendations, including the proposal that the trustees of a charity should be responsible for "the evaluation of the products of research they have funded before the results are published".

This immediately produced the criticism that neither trustees nor the institutions in which the research is carried out are often in a position to assess the intellectual quality of research results, and that this is best handled by the conventional peer review process, in particular that under which scientific and medical journals operate (see Nature 367, 100; 1995).

This conclusion now appears to have been accepted by the commissioners. Their latest proposals, which are being circulated for comment, confirm that while charity trustees must accept responsibility for the proper evaluation of the results of research before it is published, "if the results are formally published in a reputable scientific or medical journal, trustees may rely on an evaluation of quality by the journal concerned".

The proposed guidelines on the handling of intellectual property are aimed primarily at larger charities, such as the Wellcome Trust. These have been seeking clarification of the extent to which their desire to become directly involved in the exploitation of the results of research that they sponsor could conflict with their charitable status.

But the proposed guidelines have also come as a relief to some smaller medical charities. These had been concerned at the costs which would have been involved if, as earlier suggested, they had been required to seek legal protection on all patentable discoveries. "We just do not have either the resources of the staff to do that type of thing," says Martin Scott, research director of the Cystic Fibrosis Trust. David Dickson 